\title{
https://helda.helsinki.fi
}

Insubordination and the contextually sensitive emergence of if-requests in Swedish and Finnish institutional talk-in-interaction

\section{Lindström, Jan}

de Gruyter

2019-11-01

Lindström , J , Laury , R \& Lindholm , C 2019 , Insubordination and the contextually sensitive emergence of if-requests in Swedish and Finnish institutional talk-in-interaction . in $\mathrm{K}$ Beijering , G Kaltenböck \& M S Sansiñena (eds), Insubordination : Theoretical and empirical issues . Trends in Linguistics: Studies and Monographs , vol. 326 , de Gruyter , Berlin, Germany , pp. 55-78 . https://doi.org/10.1515/9783110638288

http://hdl.handle.net/10138/308523

https://doi.org/10.1515/9783110638288

unspecified

publishedVersion

Downloaded from Helda, University of Helsinki institutional repository.

This is an electronic reprint of the original article.

This reprint may differ from the original in pagination and typographic detail.

Please cite the original version. 


\title{
2 Insubordination and the contextually sensitive emergence of if-requests in Swedish and Finnish institutional talk-in-interaction
}

\begin{abstract}
This chapter reports a study of Swedish and Finnish insubordinate om and jos 'if' clauses from a synchronic perspective as the clauses emerge in interactional sequences of action. Insubordinate conditional clauses have the potential to function as complete directives without any main clauses: the recipients are able to treat them as such, responding to the directive as soon as the insubordinate clause is produced. The authors show that the emergence of insubordinate conditionals is anchored in projectable, often routinized interactional trajectories, in which the verbal action is enhanced with multimodal communication. Routinization and contextual cues play a particularly prominent role in the kind of data that are analyzed here: service encounters and medical consultations. Insubordinate conditional requests emerge in interaction in response to verbal and non-verbal actions done (and not done) by the recipients of the requests, and are thus a product of the interaction of participants in conversation.
\end{abstract}

\section{Introduction}

Conditional clauses are normally embedded as an adverbial constituent in a superordinate clause, which together build a conditional clause combination. When produced in initial position, the conditional clause then projects a superordinate clause to follow (see, e.g., Auer 2005); for example, If you heat ice $\rightarrow$ it melts. However, it is also known that in many languages, clause types ordinarily considered subordinate can, in some contexts, appear without superordinate clauses (e.g. Ford 1993; Clancy, Akatsuka, and Strauss 1997; Sansiñena, De Smet, and Cornillie 2015; Verstraete and D’Hertefelt 2016). Evans (2007) has introduced the concept insubordination to refer to the diachronic development towards syntactically independent uses of subordinate structures, or, in a synchronic view, to "the independent use of constructions exhibiting

Jan Lindström, Ritva Laury, Camilla Lindholm, University of Helsinki https://doi.org/10.1515/9783110638288-003 
characteristics of subordinate clauses" (Evans and Watanabe 2016: 2). According to Evans (2007), it is crosslinguistically common that conditional clauses are used without any superordinate clauses to make requests and offers and to express wishes - these are uses which he terms "if requests", "if wishes" and "if offers" (2007: 372). The objective of this study is to examine the contextual factors, including the speakers' embodied behavior, that contribute to the dialogic emergence and successful deployment of such 'if requests in Swedish and Finnish talk-in-interaction. By 'if' requests we mean utterances like (1) and (2), which come from service encounters conducted respectively in Swedish and in Finnish ${ }^{1}$ :

(1) Om jag får underskrift där tack.

if I get- PRS signature there thanks

'If I can have (your) signature there, please.'

(2) Sit jos saisin vielä teiän ton puhelinnumeron then if get-COND-1SG still 2PL-GEN DEM-ACC phone-number-ACC 'Then if I could still get your phone number.'

In spoken interaction, such syntactically free-standing conditional clauses mostly communicate different kinds of directive actions, but these uses have been largely ignored in reference grammars. More attention has been paid to Swedish conventionalized conditional main clauses that express unaddressed potential or irrealis wishes (Om hon bara kommer dit $i$ tid! 'If she only comes there in time'; Om du var här 'If you (only) were here') or counterfactual wishes (Om jag bara hade varit där! 'If I only had been there'). ${ }^{2}$ Finnish also has such uses, cf. Jos se vaan tulee ajoissa 'If s/he only comes in time'; Oi jospa oisin saanut olla mukana 'If only I had been able to be there'.

In what follows, we will first give an overview of some basic structural variations on Swedish and Finnish conditional clause combinations, leaving aside unaddressed desiderative or expressive uses that have been dealt with in many

1 We use the somewhat vernacular term "if' request" in this study because of its functional transparency and practicality. In an earlier study (Lindström, Lindholm, and Laury 2016), which the present one builds on, we have called these structures insubordinated conditionals used as directives (ICDs). Other terms that have been used, possibly covering a wider spectrum of phenomena than that discussed here, include "suspended" or "free conditionals" (see Lombardi Vallauri 2016).

2 For a fuller account on different functional categories of insubordinate conditional and complement clauses in Germanic languages (including Swedish), see D'Hertefelt (2015) and Verstraete and D'Hertefelt (2016). 
traditional descriptions. This background section is followed by a data presentation and an analysis that accounts for the interactional use and emergence of 'if' requests from a contextually sensitive point of view. The analysis is attuned to routinized trajectories of actions and embodied, nonverbal resources that accompany the realization of this type of directive action especially in certain kinds of institutional interaction. This study is thus a continuation to our prior work (Lindström, Lindholm, and Laury 2016), which concentrated on the sequential and structural emergence of insubordinate conditionals in both mundane and institutional interaction.

Interactional approaches to insubordination are still fairly uncommon, but we note the "dyadically dependent" analysis of insubordinate complement clauses that has been put forward by Sansiñena, De Smet, and Cornillie (2015), and specifically that of Spanish que-constructions in Gras and Sansiñena (2015); see also Floyd (2016) on “counter-assertions” in Cha'palaa. Similarly, Lombardi Vallauri's (2016) studies of conditionals in spoken Italian are of interest here. It should be noted that our analysis is concerned with a possibly initial component of a conditional clause combination which, from a canonical point of view, seems to lack a completion in the form of a superordinate consequent clause. This leaves out post-positioned conditional clauses which also may appear in a syntactically loose form, for example, as elaborative additions or re-completing increments to a prior statement (see Sansiñena, De Smet, and Cornillie 2015).

We want to stress that our analysis is strictly synchronic, based on an onlinesyntactical view of utterances and constructions emerging in talk-in-interaction here and now (see Auer 2005). For diachronic perspectives, we refer to the study by Beijering and Norde in this volume. We analyze Swedish and Finnish data in tandem in order to demonstrate general, and possibly even universal tendencies in the use of insubordinate conditional structures. In fact, there are more commonalities than differences in the usage, even though Swedish and Finnish are two structurally quite different languages: Finnish has, for example, a richer verb morphology, including dedicated person and conditional forms, while Swedish relies heavily on strict word-order patterns in marking grammatical relations.

\section{Some variations of conditional clause-combining in Swedish and Finnish}

Conditional clauses are initially marked with the subordinator om in Swedish and jos in Finnish, both corresponding to if in English. In the canonical view, the conditional clause is an adverbial clause which does not alone express an action (and 
thus, cannot stand alone); instead, it is combined with a superordinate (or matrix) clause which signifies the actual type of action, e.g. a question or a directive (Teleman, Hellberg, and Andersson 1999: 475), or expresses the condition under which the consequence in the main clause can be realized (Hakulinen et al. 2004: §1114). Swedish conditional clauses display typical features of subordinate clauses (with a fixed SVO structure and the placement of sentence adverbs, including the negator, before the finite verb), allowing the use of the modal auxiliary skulle 'would' only to convey a remote possibility in the conditional ${ }^{3}$ (Teleman, Hellberg, and Andersson 1999: 646). In Finnish, conditional jos clauses are considered subordinate adverbial clauses integrated into their main clause, but they do not differ from main clauses in terms of word order or other syntactic features. Finnish has a morphological conditional, which can freely occur in jos clauses as well (see, e.g., the example in (2) above). However, insubordinate conditional clauses are not uncommon in spoken Finnish and Swedish (e.g. Kauppinen 1998; Laury 2012; Laury, Lindholm, and Lindström 2013; D'Hertefelt 2015); in such uses, they also retain the basic internal syntactic features of a typical conditional clause.

In Swedish, a standard conditional clause combination consists of a dependent clause expressing a condition (protasis) and a main clause expressing the consequence (apodosis). The main clause has inversion, which is a structural implication of the embedding of the first clause as an adverbial constituent in the latter clause (i.e. the clause combination displays the V2 order XVS in which the conditional clause is $\mathrm{X}$ ). The examples in this section are taken from our data on institutional encounters (see Data and method below).

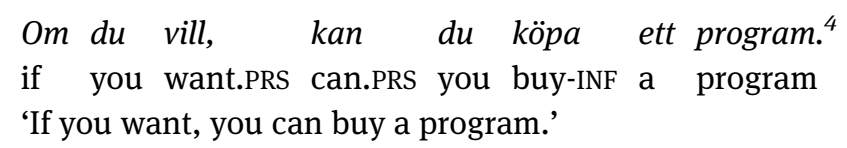

The embedded syntactic relation is often clarified with a resuming så 'so' which is inserted between the adverbial clause and the main clause. Although this så

3 This constraint parallels with that for English if-clauses in which the auxiliary should can be used to convey a tentative meaning: If you should wish to do so, please make your complaint as soon as possible (see Quirk et al. 1985: 1093).

4 The clauses can, of course, come in a reversed order, e.g. Du kan köpa ett program, om du vill 'You can buy a program, if you want'. These combinations are not very common in our data (see also Auer 2000 on spoken German, Ford 1993 on spoken English), and the conditional clause in them usually has a softening function, for example, 'if you like', 'if you want', 'if it is possible'. 
has evolved into a syntactic "dummy" it still projects the semantic relation of a consequence in the latter clause.

(4) Om du betalar för dig bara,

if you pay-PRs for you.OBJ only

så fixar vi det sen.

PRT fix-PRS we that then

'If you pay for yourself only, we (will) fix it then.'

When the conditional clause is followed by a question, the syntactic relation between the clauses is looser in that the initial clause is not embedded in the interrogative as a constituent. However, the two clauses can be bound together

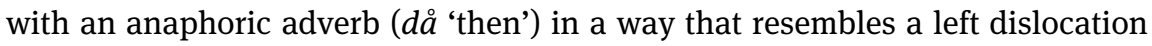
(of the conditional clause):

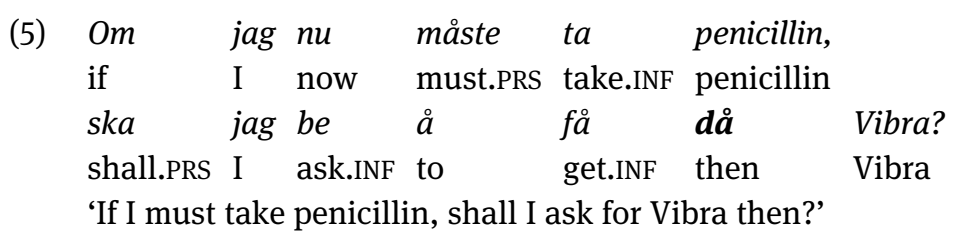

In Finnish, conditional clauses also most commonly occur in initial position (see Laury 2012: 215; Hakulinen et al. 2004: 1068), but unlike in Swedish, the word order in postposed main clauses can be direct. Since Finnish word order is, for the most part, "free", that is, pragmatically and not grammatically controlled (Vilkuna 1989), functions such as subordination are not marked by the order of constituents. In the next clause combination, concerning taking two medications at the same time, the main clause is marked as a consequent with niin 'so/then' similarly to the use of sa in Swedish.

$\begin{array}{llllll}\text { (6) jos } & \text { molempia } & \text { ottaa } & \text { sen } & \text { kolme } & \text { kertaa } \\ \text { if } & \text { both-PL-PRT } & \text { take-3SG } & \text { DEM-ACC } & \text { three } & \text { time-PRT } \\ \text { päivässä } & \text { niin } & \text { se } & \text { on, } & \text { rupee } & \text { oleen } \\ \text { day-INE } & \text { so } & \text { DEM } & \text { be-3SG } & \text { begin-3SG } & \text { be-INF } \\ \text { aika } & \text { iso } & \text { annos } & \text { sitte } & \text { jo } & \\ \text { quite } & \text { large } & \text { dose } & \text { then } & \text { already } & \end{array}$

'If (one) takes both (of them) three times a day, then it is, starts to be quite a large dose then' 
Note that in the consequent clause, initiated with niin 'then/so', the word order is direct (SVX): the subject se 'it' precedes the verb on 'is', which is then repaired to rupee oleen 'begins to be'. The adverb sitte 'then' in the consequent clause refers anaphorically to the matter expressed in the jos clause, similar to the use of $d a ̊$ in the Swedish example (5) above. ${ }^{6}$

Viewed in a straightforward manner, insubordinate 'if' requests appear to be variations of these fuller conditional clause combinations in that the latter superordinate clause (the apodosis) is left unexpressed. However, we need to achieve a better understanding of the interactional and contextual factors that produce insubordinate conditional clauses as full-fledged interactional moves. In an earlier study (Lindström, Lindholm, and Laury 2016), we have discussed the sequential emergence of insubordinate and more canonical conditional constructions showing that the process is often stepwise and dependent on local interactional contingencies, not least the conduct of the co-participant (by complying or not with a request). In the present analysis we will sharpen this picture by taking into account multimodal aspects of communication.

\section{Data and method}

When collecting cases of insubordinate conditional clauses we have consulted several hours of recordings and transcripts of them in the Finnish and Swedish conversation archives at the University of Helsinki, including face-to-face and telephone conversations and ranging from everyday to institutional settings (see Laury, Lindholm, and Lindström 2013; Lindström, Lindholm, and Laury 2016). This larger data collection contains 185 instances of insubordinate conditional clauses, 121 in Swedish, 64 in Finnish. Specifically for the present study, we have used four sub-corpora of video-recorded institutional conversations, which give a good opportunity for a multimodal analysis.

For Swedish, we have studied a corpus of medical consultations and a corpus of box office encounters at a theatre. The former consists of 14 consultations and extends to 7 hours (Melander Marttala 1995), yielding 23 instances of 'if' requests; the latter consists of 83 brief encounters which amount to 3 hours

5 The subject se 'it' could be interpreted as representing the amount of medication resulting from taking both medications three times a day, which is then evaluated in predicate nominal as being a large dose.

6 As in Swedish (see note 4), Finnish conditional clauses can also come after the main clause, e.g. Tähän voi maksaakin, jos haluatte 'It's possible to pay here too, if you like'. 
in total (Norrby et al. 2015) and contains six instances. In the majority of the cases it is the institutional party (physician or seller) who produces the request, but there are some instances in the service encounters in which the customer also uses an insubordinate conditional as a request.

The Finnish corpus consists of customer visits to a pharmacy and consultations with a small animal veterinarian. In the pharmacy data, there are altogether 58 customer visits. In these data, insubordinate conditionals are relatively rare; there are only four of them in 5 hours and 32 minutes of videotape. They also have a fairly routine context of use, as all but one involve requests for a telephone number. Insubordinate conditionals are slightly more common in the veterinary data consisting of 17 videotaped visits with a total duration of 3.5 hours and containing 7 'if' requests. All involve requests the veterinarian addresses to the pet owners, similar to the pharmacy data where all the insubordinate conditionals are requests made by the pharmacist to the customer. Thus, while the total duration of the Finnish data is comparable to the Swedish data, the number of insubordinate conditionals is smaller, only one third of what was found in the Swedish data (11 to 29).

The analytic methods are rooted in the traditions of Conversation Analysis and Interactional Linguistics (see Couper-Kuhlen and Selting 2001) augmented by a multimodal interaction analysis (see Mondada 2016). We thus pay special attention to the sequential, turn-by-turn emergence of speaker contributions and their grammatical shaping in conversational interaction as it is unfolding in real time. Moreover, the analysis keeps track of the coordination of verbal, embodied and other contextual resources utilized in communication.

\section{Contextual and embodied resources in the emergence of 'if' requests}

In an earlier study based on our larger data collection with more than a hundred instances (Laury, Lindholm, and Lindström 2013), we concluded that Swedish and Finnish insubordinate conditional clauses function most commonly as directives, i.e. to communicate actions which are designed to get someone to do something (see Ervin-Tripp 1976). These directives included the subcategories of suggestions, requests and proposals. ${ }^{7}$ We have also noticed

7 In a suggestion, the agent as well as the beneficiary is Other, in a request, the agent is Other and the beneficiary is Self, in a proposal, both Self and Other are agents and beneficiaries (for this categorization of directive actions, see Couper-Kuhlen 2014). 
that it is crucial for the dialogic emergence of 'if' requests that their use and interpretation is anchored in projectable interactional trajectories, in which the verbal action is enhanced with multimodal communication. This comes across in a prominent way in our sub-corpora of institutional interactions, which display routinized series of actions. The following extract, taken from a box office encounter, in which the customer is requesting a ticket from a staff member seated at a desk, illustrates both the use of a full conditional om clause combined with a consequent clause (1. 02-04) and a free-standing 'if' request (1. 09); in this extract and the following ones, the conditional clauses functioning as 'if' requests are highlighted in bold.

(7) Signature (055) ( $\mathrm{S}=$ staff, $\mathrm{C}=$ customer)

$01 \mathrm{~S}:$ nu vill den int göra någo. (0
now want-PRS it NEG do-INF anything
'now it isn't co-operating at all'
02 hom ja drar de här via min så
if I draw-PRS this here via mine so
'if I draw it here through mine'
(.) ((C gives her card to S))
03 funkar de säkert [\#bättre\#] (s-)
work-PRS it surely good-comP

'it probably works better'

$05 \mathrm{C}$ :

$\begin{array}{ll}\text { [jå } & \text { 'yes' }\end{array}$

$06 \quad(2.8)$ ((S draws C:s card through card terminal))

07 S: \#jes\# så $\quad$ där. (( g gives card back to $C)$ ) PRT like this

'yes, here we go'

08

09 S: mt s:å om ja få(r) underskrift \#dä:r\# *itack. So if I get-PRS signature there thanks 'if I can get your signature here, please'

$*((C$ looks down at the invoice $\mathrm{S}$ has placed on the desk and reaches for a pen)) (2.1) 
$\begin{aligned} 11 \text { C: blev de } \text { iändå femtifyra?, } & \text { become.PST it still fifty-four } \\ & \text { 'oh, it ended up being fifty-four anyway?' }\end{aligned}$

The extract is initiated by a comment from the staff member on the slow functioning of the customer's card terminal; the Swedish verb vill ('want') is used to describe the functional problems, ascribing the card terminal intentionality (i.e. a will of its own). This comment is followed by the staff member's proposal to deal with the customer's card in her own terminal. The proposal carries the form of a complex sentence expressing both the condition ('if I draw it through mine') and the consequent ('it probably works better'). The customer hands over her credit card and the staff member draws it through the card terminal. After handing over the card to the customer and tearing an invoice out from the terminal, the staff member makes a request to the customer to sign. In contrast to her previous directive move, this one (1. 08) has the form of a free-standing 'if' request. The verbal action is formed as a syntactically, prosodically and pragmatically complete “package”. The turn-final tack ('please') does not project a continuation, rather, it re-completes the turn. The 'if' request is accompanied by the non-verbal action of handing over the invoice to the customer, who examines the invoice and takes a pen in her hand, thus signaling that she is about to comply and sign (see Figure 1); however, before signing, the customer asks for a clarification of the sum to be paid (1. 11).

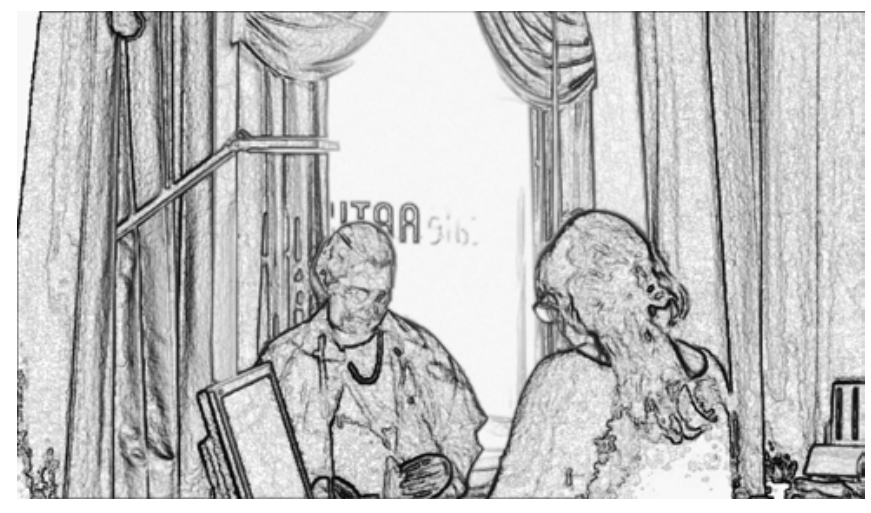

Figure 1: The staff member hands over an invoice to the customer (facing the camera) simultaneously producing an 'if' request; the customer reaches for a pen to sign after the completion of the request; line $09-10$ in extract (7). 
The insubordinate conditional is produced in a routine transactional slot and it is combined with a physical action that enhances its interpretation, i.e. handing over a transactionally relevant artefact. The consecutive trajectory is hereby so strongly projected that it need not be said: compliance enables the completion of the purchase. Moreover, the customer's visible readiness to comply, conveyed by embodied action, makes a further elaboration of the request unnecessary.

The next extract, taken from a corpus of Swedish medical consultations, provides another illustration of a conditional om clause treated as a full-fledged request.

(8) Relax (LOP 1:9) (D=doctor, $\mathrm{P}=$ patient)

01 D: mm. kan du ta å göra så här?, PRT can you take.INF and do-INF so here 'Mm. Can you do like this?'

02 (2.0) ((D lifts his hands behind his neck; $P$ repeats the movement))

03 D: bra. (0.5) å så tibaka. good and so back

'Good. And then back again.'

04 (3.0) ((D takes $\mathrm{P}^{\prime}$ s arms to a downward position))

05 D: hh så< (.) $\begin{array}{ll}\text { om du *slappnar av }{ }^{\circ} \text { där så } \\ \text { so } & \text { if you relax-PRS PRT there so }\end{array}$

'So (.) if you relax there'

*((D twists P's left arm))

06

$(4.0)$

$07 \mathrm{D}: \mathrm{mm}$. (0.5) jaha du har inte ont $i$ nacken PRT PRT you have-PRS NEG ache in neck-DEF

'Mm. Right, your neck isn't sore'

In the context of a physical examination, the doctor asks the patient to lift his hands up behind his neck (1. 01). The doctor first demonstrates the movement himself, and the patient complies with the request by repeating the doctor's movement (Figure 2a). The doctor assesses the patient's action (1. 03), and then continues by giving a verbal and an embodied instruction for further action; he first says 'and then back again', takes hold of the patient's arms and brings 


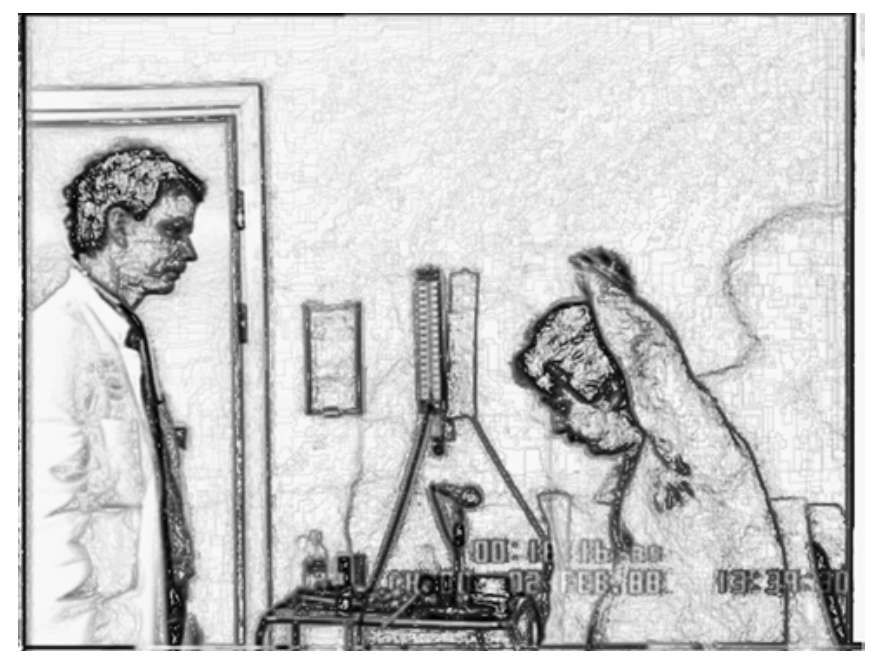

Figure 2a: The patient lifts his hands up behind his neck; line 02 in extract (8).

them back to the starting position in front of the body. The instruction to relax is expressed in a conditional clause (1.05) and initiates a new sub-phase in the physical examination; the doctor puts his hands on the patient's left arm and makes a twisting movement. Note that the om request includes a final så ('so'). As mentioned earlier, så is often used to clarify the relation between the conditional clause and the main clause in standard conditional clause combinations. In this case, and recurrently in the doctor-patient data, så marks the request/ compliance interface: the production of så matches the completion of the arm movement to a relaxed down position (Figure 2b). In other words, rather than projecting a consequent to follow, så marks completed action, which is one of its many functions as an adverb (see Ottesjö and Lindström 2005). The doctor then goes on to performing the physical action (inspecting the arms) without any consecutive verbal expression referring to this action (1.06). Such a verbal specification is made redundant by the fact that the doctor, through holding his hands on the patient's arm, can feel that the patient has complied by muscular relaxation.

In extracts (7) and (8) the 'if' requests were successful and complied with by the requestees. The next extract, taken from the corpus of box-office encounters, shows an instance where the request does not function in its own right. The staff member asks for the customer's telephone number. The customer, who is unfamiliar with the institution's practice of using the phone number to confirm the booking/purchase, reacts with confusion. Instead of providing the 


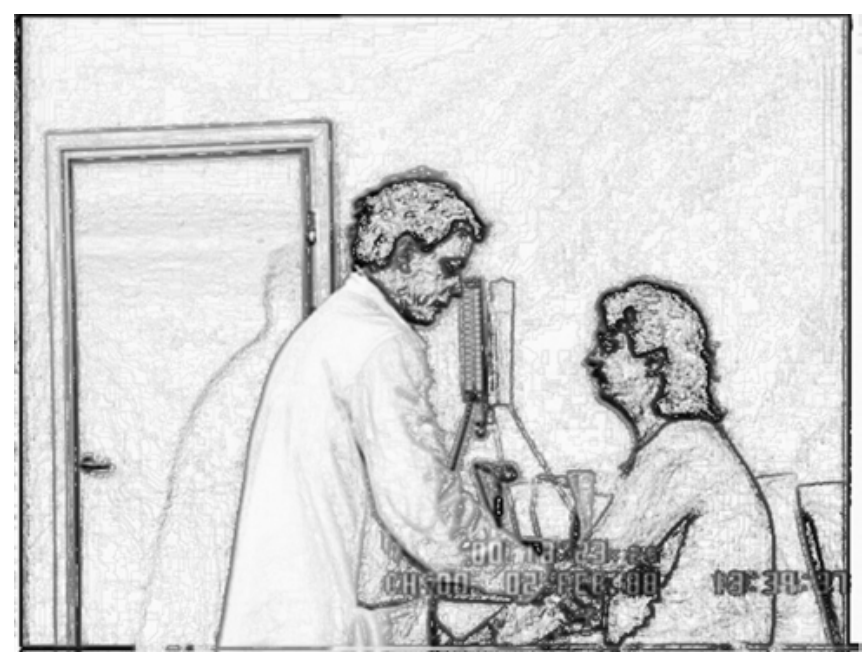

Figure $\mathbf{2 b}$ : The doctor holds the patient's arm when producing an 'if' request to relax, line 05 in extract (8).

asked-for number, the customer initiates a repair, signaling difficulty in hearing and understanding the previous move (1.03). Thus, the staff member is asked to repeat and/or clarify the request expressed in line 01.

(9) Telephone number (088) ( $\mathrm{S}=$ staff, $\mathrm{C}=$ customer)

$01 \mathrm{~S}:$ om ja får ert telefonnummer ännu så. if I get-prs your.v telephone-number yet PRT 'If I can have your phone number then' (1.8) ((C looks confused, turns head closer to $S)$ )

$03 \mathrm{C}$ : ett (ett va sa) ett telefonnum[mer]?, a a what say-PST a telephone-number

'A, (a what did you say), a phone number'

$04 \mathrm{~S}:$

'yes'

05 ja måst få in den som en bokning I must.PRS get.INF in it as a booking 'I must register it as a booking' 
06

före ja kan sälja den.

before I can sell-INF it

'before I'm able to sell it'

07 C: jaha. (0.4) eh (.) nu de e alltså-

PRT PRT now it is PRT

'okay, eh well, then it's a-

08 svensk mobil eh telefonnummer då.

Swedish mobile PRT telephone-number then

'Swedish mobile eh phone number then'

09 S: då sätter ja plus [förtisex] på den.

then put-PRS I plus forty-six on it

'then I'll put plus forty-six on the number'

$10 \mathrm{C}:$

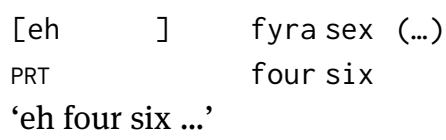

The customer's request for clarification is followed by an account by the staff member (1. 05-06). The account has the character of an (unexpressed) consequent indicating the reason for the 'if' request, e.g. 'If I can have your phone number (I can register a booking and sell the ticket)'. Note that the conditional clause in line 01 ends with a final så 'so', which, albeit not prosodically continuation-projecting, implies some sort of consecutive course of events by marking the request/compliance interface (see also extract (8) above). After the staff member has produced the account, the customer initiates the requested action of providing her phone number and the transactional business moves on. ${ }^{8}$

Extract (9) then provided an illustration of a case in which the 'if' request was not successful, as the other party did not have the necessary contextual knowledge of a routine transactional trajectory. ${ }^{9}$ Generally, it is not evident what is left unpronounced in 'if' requests without a follow-up consequent but

8 We do not reproduce the customers' actual phone numbers in extracts (9) and (10) but only the beginning of the number series consisting of the country/operator prefix to indicate that the recipient complies with the request by producing a series of numbers.

9 Arguably, the unsuccessful outcome of the 'if' request in (9) does not depend on the insubordinate conditional format as such but on the lack of contextual cues. Our point is that the extract lucidly illustrates what kind of content may be left unexpressed in conditional directives, namely, the beneficial consequences of the requested action (e.g. 'If you do $\mathrm{x}$, I can do y'). 
the implication is that it has to do with an outcome that is beneficial for the requester or possibly also for the requestee. In (9) the subsequent account makes this inferable relation explicit and is necessary for the action to continue, since it is called for by a repair initiative. However, in our data, extract (9) constituted an exception: insubordinate conditional requests are normally treated as sufficient to perform requested actions.

Our next example comes from our Finnish corpus of drugstore visits, and like the previous Swedish excerpt, involves a request for a phone number. As is common at Finnish pharmacies, the customer is sitting at the counter across from the pharmacist who has a computer screen in front of her. In all the cases with the Finnish jos requests in our pharmacy data, the medication the customer has a prescription for is not available; as a result, the pharmacist asks the customer for a phone number so the customer can be called when the medication arrives from the wholesaler. Here, it has been established already that the medication will be delivered at the pharmacy the next day.

(10) Apteekki 69W ( $\mathrm{P}=$ pharmacist, $\mathrm{C}=$ customer)

$\begin{array}{cllll}01 \mathrm{P}: \text { joo. } & \text { maksatteko } & \text { nyt } & \text { vai: } & \text { noutaessa= } \\ \text { PRT } & \text { pay-2PL-Q } & \text { now } & \text { or } & \text { fetch-INF-INE }\end{array}$

'ok. will you pay now or when you pick up?'

$02 \mathrm{C}$ : =huomenna sitte joo

tomorrow then PRT

'tomorrow then, yeah'

03

$\begin{array}{llll}\text { onks } & \text { se } & \text { mihi aikaa } \\ \text { be-Q-CLT } & \text { DEM } & \text { wh-ILL time-ILL } \\ \text { 'what time will it be?' }\end{array}$

$04 \mathrm{P}$ : .hhh noo ne tavarat tulee meille yleensä

PRT DEM thing-PL come-3SG 1PL-ALL usually

'well the goods are delivered usually'

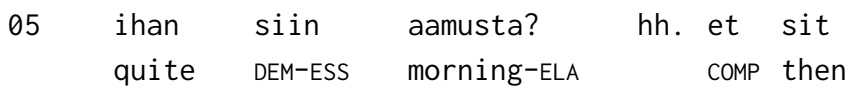

'first thing in the morning, so then'

06 sit jos on kiire niin me käyään tuolla

then if be.3SG hurry so 1PL go-PASS DEM.LOC-ADE

'if it is urgent we go over there' 
07 penkoon ne läpi mut yleensä me ollaan ehitty dig-INF 3PL through but usually 1PL be-PASS have.time 'and dig through but usually we will have had time'

08 saada niinku ne kaikki [niinku purettua get-INF PRT DEM.PL all PRT unpack-PPL-PAR 'to get them all like unpacked like'

09 niin iltapäivällä

so afternoon-ADE

'by the afternoon'

$10 \mathrm{C}$ :

11 C: okei

PRT

'ok'

12 P: .hh me ollaan *kymmenest neljään

$1 \mathrm{PL}$ be-PRES.PASS ten-ELA four-ILL 'we are (open) from ten to four'

*((Pharmacist moves to the left of the computer and opens a drawer))

13 C: joo

PRT

'yeah'

$14 \mathrm{P}$ : tota

PRT

'um'

15 C: voiks nää maksaa .hhhh

can-Q-CLT DEM.PL pay-INF

'can I pay for these?'

$16 \mathrm{P}$ : anteeks

apology-TRA

'pardon'

17 C: voik- voiks nää maksaa sulle tähä [vai can- can-Q-CLT DEM.PL pay-INF 2SG-ALL DEM-ILL or 'can- can (I) pay for these here to you or?' 
$18 \mathrm{P}$ :

[ne voi

DEM.PL can

'you can'

19

$\begin{array}{llllll}\text { maksaa } & \text { mulle } & \text { *mut } & \text { jos } & \text { mä vielä saisin } \\ \text { pay-INF } & 1 \mathrm{SG}-\mathrm{ILL} & \text { but } & \text { if } & 1 \mathrm{SG} \text { still get-COND-1SG }\end{array}$

'pay me for them but if I could still get'

20 teiän puhelinnumeron

2PL-GEN phone-number-ACC

'your phone number'

*( (Pharmacist gets pen ready and bends over a piece of paper))

21 C: joo nolla viis nolla $((. .)$.$) .$

PRT zero five zero

'yeah, zero five zero ...'

22 P: joo

PRT

'yeah'

Having been established just prior that the prescribed medication would not be available until the next day, the customer asks about the time he could pick up his prescription (1. 03). Once this has been worked out, the pharmacist moves over to her left in search of what turns out to be a piece of paper (1. 12), which she puts down on the desk. While doing this, she misses the customer's question about paying for his other purchases (1.13-14), and there is a repair sequence (1. 15-16). Immediately after answering the customer's question (1. 17), the pharmacist makes her 'if' request. It is remarkably similar to the 'if' request in the Swedish example in (9). Besides being formatted as 'if' requests, both requests are done with the $\mathrm{V}$-form, i.e. second person plural address pronoun (ert and teiän, respectively), and both contain an item, the Swedish ännu and the Finnish vielä, roughly equivalent to the English 'still, yet', indexing that the phone number is the next item due which needs to be established before the transaction is complete. Here, the phone number request is projected by embodied actions, the pharmacist's going over to the drawer to get the piece of paper for writing down the number (1. 12), as well as her bending over the paper and getting a pen ready to write (1. 19-20). The latter embodied action is timed so it begins exactly when the jos request is initiated. Unlike the Swedish request, this 'if' request is unproblematic, and the customer complies with the 
projected action, giving the phone number without delay. No verbal consequent is produced, and the transaction is brought to a close.

This is not the case with the 'if' requests the veterinarian makes to the owners of the pets examined in our other set of Finnish data. As noted by Somiska (2010), in each case, there is a consequent. However, the pet owner, to whom the 'if' request is addressed, complies with the request before the consequent is issued, both by doing the action requested and also, in most cases, with a verbal item doing compliance. Consider the following excerpt, in which the veterinarian is examining a turtle.

(11) SG 436 Konna (V=veterinarian, $\mathrm{O}=$ owner)

$01 \mathrm{~V}$ : \#mä laitan\# painon tohon ylös

1SG put-1SG weight-ACC DEM-ILL up

'I will put down the weight over there'

02 ennen $\mathrm{ku}$ mä $\uparrow u n o h d a n$ 个sen?, before PRT 1SG forget-1SG DEM-ACC

'before I forget it'

$(0.5)$ ((Vet places turtle on table, facing the owner ))

03 V: vähäj jos otat *vasta[an ettei lähe, a.little if take-2sG against COMP-NEG leave 'if you would hold it a little so (it) won't start (getting)'

$$
\text { *((Owner places hands on turtle }))
$$

04 0:

$[$ joo

PRT

'ok'

$(1.0)$

$05 \mathrm{~V}$ : pöyält alas $=>\mathrm{kyl}$ ne $<$ monestit tohon pöydän table-ABL down PRT DEM.PL often DEM-ILL table-GEN 'down from the table, they do often at the table's'

06 reunalle kun ne menee ni [sit ne sillai, edge-ALL when DEM.PL go-3SG so then DEM.PL DEM-MANN 'edge when they go, so then they (seem to think) like'

070 :

[\#mmm\#

$08 \mathrm{~V}:(0.8) \quad(($ Vet mimics a turtle $))$

09 0: £mheh heh heh he .hhh£ 


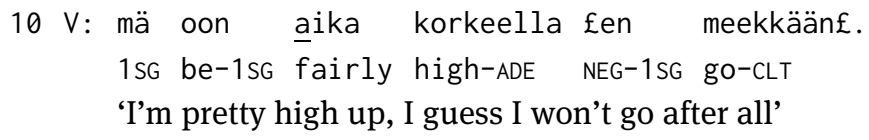

At this point in the visit, the veterinarian has just weighed the turtle, has lifted it off the scales and is examining its nose, the trouble spot, holding the turtle close to her face. She then announces that she will write down the turtle's weight (1. 01-02). The owner is standing on the opposite side of the examining table from the vet. The vet turns the turtle around, places it on the examining table, holding it with two hands so that it is facing its owner, and issues the jos request. Before the veterinarian's hands are off the turtle, and before the word vastaan is said, the owner reaches out her hands and grabs the turtle as the veterinarian releases it, (Figure 3), and then produces a verbal compliance, joo 'yeah' (line 04), showing again that the insubordinate conditional functions independently as a request.

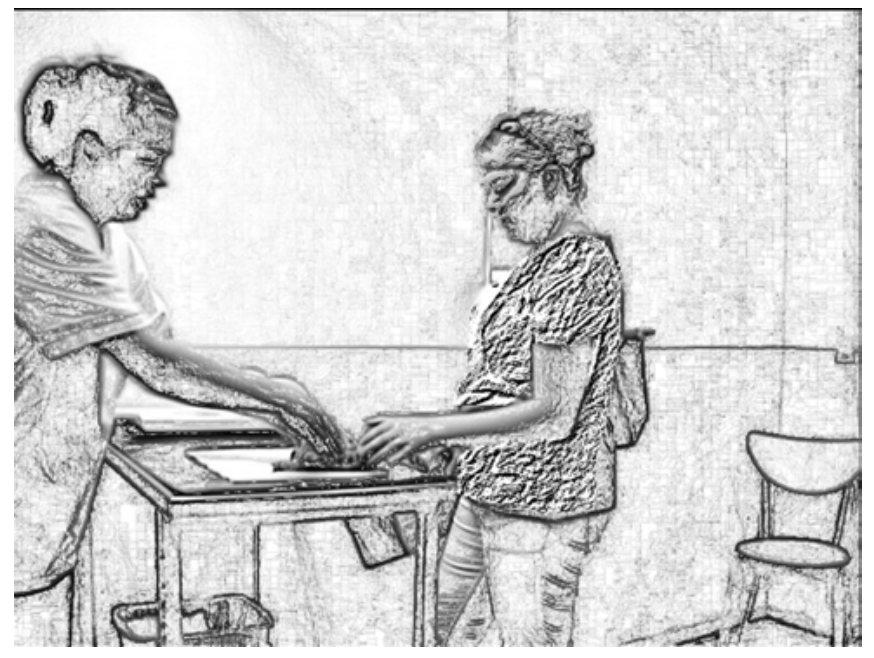

Figure 3: The veterinarian places the turtle on the table when producing an 'if' request to the customer to hold the turtle; the customer places her hand on the turtle; line 3 in extract (11).

In this excerpt, the consequent is in the form of a negative consecutive ettei * so+NEG' clause, which follows the jos request immediately. However, the owner's compliance, both verbal and embodied, comes before the ettei clause begins. It is also true that the veterinarian's request is projected by her embodied action of placing the turtle on the table facing the owner, so that she can 
comfortably reach her pet; also, the imminent action of taking her hands off the turtle calls for an action from the owner, to take care of the turtle. Thus we can see that the 'if' request is projected by an embodied preface and complied with by another embodied action before the consequent is produced. Note also that the request is mitigated immediately after the consequent; latched with the consequent clause ettei lähe pöyält alas 'so it won't get off the table', the vet explains that when the turtle gets to the edge of the table, it is able to see how high up it is, and changes its mind - thus holding the turtle might not be necessary after all. This subsequent hedging probably does politeness work in the institutional context in which directives to the customer may be dispreferred.

\section{Conclusions}

In this article, we have discussed the use of insubordinate conditional jos and om 'if clauses as directives in Finnish and Swedish conversation. We showed that such conditional clauses are responded to by the recipients of the directives in ways which show that they do not wait for a main clause to be produced readiness to comply may be signaled either verbally or through embodied action. This indicates that such 'if' requests are conventionalized as directives and function as such without projecting a consequent (an apodosis) to emerge; in most of our instances, the issuer of an 'if' request does not show any orientation (for example, prosodically) to continue past the conditional move. These facts would suggest that the Finnish and Swedish usage has reached the final stage 4, i.e. full conventionalization and reanalysis as a main clause, in Evans' (2007) model of the evolutionary trajectory towards insubordination.

On the other hand, the emergence of insubordinate om and jos 'if' directives is contextually sensitive to a high degree, enhanced by situational and embodied resources in communication. Although the verbal consequent is left unsaid, a consecutive trajectory of action is strongly projected in the service encounter and medical interaction data we have analyzed. Thus, the 'if' requests are produced together with embodied actions which facilitate action ascription, for instance, by handling a transactionally relevant artefact (such as an invoice to sign, a paper and a pen to make notes with). Similarly, familiarity with the routine trajectory of actions, for example, knowledge of what kind of information is relevant to be produced where and when, helps identify the target of the directive move. We could even say that the whole array of these contextual resources - consisting of talk (the 'if' request proper), embodied action (bodily 
orientation), situational affordances (artefacts projecting a measure) and transactional "scripts" for the order of actions - render the production of a consequent clause to an 'if' request redundant. Rather, the consequent is something that is produced when it becomes apparent that the contextual cues do not work for a successful identification of the directive action (see extract (9) above and Lindström, Lindholm and Laury 2016 for further examples). In this sense, the "free-standing" nature of 'if' requests is strongly relativized as they in practice do not occur independently from other (i.e. nonverbal) communicative resources which may communicate the "consequent", i.e. the relevance of the asked-for action for the subsequent trajectory of actions. These features then would place the evolutionary status of Finnish and Swedish 'if' requests closer to stage 3 in Evans' (2007) model for the process of insubordination, i.e. "conventionalized ellipsis" which involves some restriction of pragmatic interpretation (cf. Lombardi Vallauri 2016 on Italian).

However, we find that there are reasons to take a critical stance to Evans' (2007) stepwise evolutionary model, which builds on the concept of ellipsis before the stage of conventionalization. We can see in our data that the 'if' requests are clearly understood as directives, and complied with, even when the main clause is subsequently produced and no ellipsis, in effect, has taken place, e.g. in extract (11) above. Furthermore, the ellipsis explanation may not be adequate if one takes into account ontogenesis: Kauppinen (1998) shows that insubordinate jos 'if' requests emerge in Finnish child language acquisition prior to the embedded use of 'if' clauses; thus, it does not seem logical that any main clause is ellipted, since the child has not acquired the clause combination yet. Against this background it is not quite clear that the emergence of insubordinate 'if' requests of the type we have studied here can be fitted into the Evans model.

Generally, by involving conditionality, 'if' requests suspend the consequences that the nominated action would have, i.e. they are not verbalized. Such directives are less direct in that they thus leave room for interpretation for the recipient as to the desirability of the proposed action. This kind of conditional indirectness can be seen as an orientation towards the dispreferred nature of many directive actions and may be useful, for example, in service encounters. There is also a noticeable element of mutual sensemaking in the deployment of 'if' requests in that they emerge on-line, as collaborative actions of the participant issuing the directive and their addressees, and in response to the actions performed by both participants. Such coactivity, which involves recognition of upcoming interactional trajectories, builds on intersubjectivity, i.e. a sufficient level of shared understanding between the interlocutors. 
Acknowledgments: The research reported in this study was conducted in the Finnish Centre of Excellence in Research on Intersubjectivity in Interaction, based at the University of Helsinki (intersubjectivity.fi). The data from Swedish box-office encounters were collected for the research program Interaction and Variation in Pluricentric Languages (IVIP), funded by Riksbankens Jubileumsfond (Grant M120137:1). The data on Swedish medical consultations was collected and processed by Ulla Melander Marttala for her doctoral thesis, and the Finnish data were videotaped and transcribed by Päivi Hakamäki (the pharmacy data) and by Outi Somiska (the veterinary data) for their MA theses; we thank all of them for their generosity in sharing their data with us. We have slightly modified their transcripts. We also want to thank the editors of this volume and two anonymous reviewers for their very useful comments on an earlier version of this chapter.

\section{References}

Auer, Peter. 2005. Projection in interaction and projection in grammar. Text 25 (1). 7-36.

Clancy, Patricia M., Noriko Akatsuka \& Susan Strauss. 1997. Deontic modality and conditionality in discourse. A cross-linguistic study of adult speech to young children. In Akio Kamio (ed.), Directions in functional linguistics, 19-57. Amsterdam: Benjamins.

Couper-Kuhlen, Elizabeth. 2014. What does grammar tell us about action? Pragmatics 24 (3). 623-647.

Couper-Kuhlen, Elizabeth \& Margret Selting. 2001. Introducing interactional linguistics. In Margret Selting \& Elizabeth Couper-Kuhlen (eds.), Studies in interactional linguistics, 1-22. Amsterdam: Benjamins.

D'Hertefelt, Sarah. 2015. Insubordination in Germanic: A typology of complement and conditional constructions. Leuven: University of Leuven dissertation. https://lirias.kuleuven.be/handle/ $123456789 / 509450$.

Ervin-Tripp, Susan. 1976. Is Sybil there? The structure of some American English directives. Language in Society 5 (1). 25-66.

Evans, Nicholas. 2007. Insubordination and its uses. In Irina Nikolaeva (ed.), Finiteness: theoretical and empirical foundations, 366-431. New York: Oxford University Press.

Evans, Nicholas \& Honoré Watanabe. 2016. The dynamics of insubordination. In Nicholas Evans \& Honoré Watanabe (eds.), Insubordination, 1-37. Amsterdam: John Benjamins.

Floyd, Simeon. 2016. Insubordination in interaction. The Cha'palaa counter-assertive. In Nicholas Evans \& Honoré Watanabe (eds.), Insubordination, 341-365. Amsterdam: Benjamins.

Ford, Cecilia E. 1993. Grammar in interaction. Adverbial clauses in American English conversation. Cambridge: Cambridge University Press.

Gras, Pedro \& Maria Sol Sansiñena. 2015. An interactional account of que-constructions in Spanish. Text \& Talk 35 (4). 505-529.

Hakulinen, Auli, Maria Vilkuna, Riitta Korhonen, Vesa Koivisto, Tarja-Riitta Heinonen \& Irja Alho. 2004. Iso suomen kielioppi [The comprehensive grammar of Finnish.] Helsinki: Suomalaisen Kirjallisuuden Seura. 
Kauppinen, Anneli. 1998. Puhekuviot, tilanteen ja rakenteen liitto: tutkimus kielen omaksumisesta ja suomen konditionaalista. [Speech patterns, a union of context and structure: a study of language acquisition and the Finnish conditional.] Helsinki: Suomalaisen Kirjallisuuden Seura.

Laury, Ritva. 2012. Syntactically non-integrated jos 'if' conditionals as directives. Discourse Processes 49 (3-4). 213-242.

Laury, Ritva, Camilla Lindholm \& Jan Lindström. 2013. Syntactically non-integrated conditional clauses in spoken Finnish and Swedish. In Eva Havu \& Irma Hyvärinen (eds.), Comparing and contrasting syntactic structures. From dependency to quasi-subordination, 231-270. Helsinki: Société Néophilologique.

Lindström, Jan, Camilla Lindholm \& Ritva Laury. 2016. The interactional emergence of conditional clauses as directives: constructions, trajectories and sequences of action. Language Sciences 58. 8-21.

Lombardi Vallauri, Edoardo. 2016. Insubordinated conditionals in spoken and non-spoken Italian. In Nicholas Evans \& Honoré Watanabe (eds.), Insubordination, 145-169. Amsterdam: Benjamins.

Melander Marttala, Ulla. 1995. Innehåll och perspektiv i samtal mellan läkare och patient: en språklig och samtalsanalytisk undersökning. [Content and perspective in doctor-patient conversations: a linguistic and conversation analytic investigation.]. Uppsala: Uppsala University dissertation.

Mondada, Lorenza. 2016. Challenges of multimodality: language and the body in social interaction. Journal of Sociolinguistics 20 (3). 336-366.

Norrby, Catrin, Camilla Wide, Jenny Nilsson \& Jan Lindström. 2015. Address and interpersonal relationships in Finland-Swedish and Sweden-Swedish service encounters. In Catrin Norrby \& Camilla Wide (eds.), Address practice as social action. European perspectives, 75-96. Houndsmills, Basigstoke Hampshire: Palgrave Macmillan.

Ochs, Elinor, Emanuel A. Schegloff \& Sandra A. Thompson (eds.). 1996. Interaction and grammar. Cambridge: Cambridge University Press.

Ottesjö, Cajsa \& Jan Lindström. 2005. Så som diskursmarkör ['So' as a discourse marker]. Språk och stil 15. 85-127.

Quirk Randolph, Sidney Greenbaum, Geoffrey Leech \& Jan Svartvik. 1985. A comprehensive grammar of the English language. London: Longman.

Sansiñena, Maria Sol, Hendrik De Smet \& Bert Cornillie. 2015. Between subordinate and insubordinate. Paths toward complementizer-initial main clauses. Journal of Pragmatics 77. 3-19.

Somiska, Outi. 2010. Eläinlääkärin pehmeät direktiivit. [The veterinarian's soft directives.]. Helsinki: University of Helsinki, Department of Finnish MA thesis.

Teleman, Ulf, Staffan Hellberg \& Erik Andersson. 1999. Svenska Akademins grammatik. [The Swedish Academy grammar.] Volume 4. Stockholm: Svenska Akademien.

Verstraete, Jean-Christophe \& Sarah D'Hertefelt. 2016. Running in the family. Patterns of complement insubordination in Germanic. In Nicholas Evans \& Honoré Watanabe (eds.), Insubordination, 65-87. Amsterdam: Benjamins.

Vilkuna, Maria. 1989. Free word order in Finnish: its syntax and discourse functions. Helsinki: SKS. 


\section{Appendix}

Transcription symbols (cf. Ochs, Schegloff, and Thompson 1996: 461-465)

\begin{tabular}{|c|c|}
\hline & falling intonation \\
\hline & level intonation \\
\hline ; & slightly falling intonation \\
\hline$?$ ? & slightly rising intonation \\
\hline$?$ & rising intonation \\
\hline$\uparrow$ & rise in pitch \\
\hline en & emphasis indicated by underlining \\
\hline : & lengthening of a sound \\
\hline [ & utterances starting simultaneously \\
\hline & point where overlapping talk stops \\
\hline (.) & micropause, less than 0.2 seconds \\
\hline$(0.5)$ & silences timed in tenths of a second \\
\hline$><$ & talk inside is at a faster pace than the surrounding talk \\
\hline$\langle>$ & talk inside is at a slower pace than the surrounding talk \\
\hline en< & glottal stop \\
\hline en- & cut off \\
\hline$=$ & "latching”, i.e. no silence between two adjacent utterances \\
\hline \#en\# & creaky voice \\
\hline fenf & smile voice \\
\hline${ }^{\circ} \mathrm{en}^{\circ}$ & talk inside is more quiet than the surrounding talk \\
\hline (en) & uncertain transcription \\
\hline() & inaudible words \\
\hline $\mathrm{hh}$ & audible exhalation (the more $h$ 's, the more aspiration) \\
\hline. $\mathrm{hh}$ & audible inhalation (length as above) \\
\hline * & point of coordinated verbal and non-verbal action \\
\hline ((reaches for a pen)) & specification of the type of non-verbal action \\
\hline$((\ldots))$ & omitted verbal material \\
\hline
\end{tabular}

\section{Glossing abbreviations}

$\begin{array}{ll}\text { ABL } & \text { ablative } \\ \text { ACC } & \text { accusative } \\ \text { ADE } & \text { adessive } \\ \text { ALL } & \text { allative } \\ \text { CLT } & \text { clitic } \\ \text { COMP } & \text { complementizer } \\ \text { COND } & \text { conditional } \\ \text { COP } & \text { copula } \\ \text { CMP } & \text { comparative } \\ \text { DEF } & \text { definite } \\ \text { DEM } & \text { demonstrative }\end{array}$




$\begin{array}{ll}\text { DET } & \text { determiner } \\ \text { ELA } & \text { elative } \\ \text { ESS } & \text { essive } \\ \text { FN } & \text { first name } \\ \text { GEN } & \text { genitive } \\ \text { GNR } & \text { generic 3rd person pronoun (cf. 'one') } \\ \text { ILL } & \text { illative } \\ \text { IMP } & \text { imperative } \\ \text { INE } & \text { inessive } \\ \text { INF } & \text { infinitive } \\ \text { IINF } & \text { 1st infinitive } \\ \text { LN } & \text { last name } \\ \text { NEG } & \text { negation } \\ \text { PAR } & \text { partitive } \\ \text { PASS } & \text { passive } \\ \text { PL } & \text { plural (1PL reads 'first person plural') } \\ \text { PRS } & \text { present tense }{ }^{10} \\ \text { PRT } & \text { particle } \\ \text { PST } & \text { past tense } \\ \text { PTC } & \text { participle } \\ \text { REFL } & \text { reflexive (pronoun) } \\ \text { SG } & \text { singular (1sG reads 'first person singular') } \\ \text { TRA } & \text { translative } \\ \text { Q } & \text { question clitic } \\ \text { V } & \text { second person politeness form } \\ \text { VOC } & \text { vocative } \\ \text { WH } & \text { wh-question word } \\ & \end{array}$

10 Present tense and nominative case are default for Finnish glossing and are not marked. 